\title{
Nasal paraganglioma
}

\author{
Nazal paragangliyom \\ Ömer Sağlam, ${ }^{1}$ Engin Dursun, ${ }^{1}$ Uğur Karapınar, ${ }^{2}$ Bilal Çetin ${ }^{3}$ \\ ${ }^{1}$ Department of Otolaryngology, Kasımpaşa Military Hospital, İstanbul, Turkey

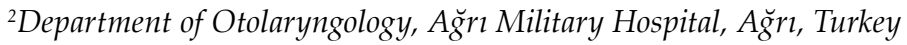 \\ ${ }^{3}$ Department of Otolaryngology, Gümüşsuyu Military Hospital, İstanbul, Turkey
}

\begin{abstract}
Paragangliomas are rare neuroendocrine neoplasms of extraadrenal autonomic nervous system. These are usually benign, slow growing vascular tumors found in the abdomen, thorax, head and neck region. Head and neck paraganglioma is primarily located in the temporal bone and carotid body. Paragangliomas of nose and paranasal sinus are extremely rare and a few case reports are available. In this article we report a 25-year-old female patient with nasal paraganglioma suffering from nasal obstruction and nasal bleeding in the light of literature data.

Key Words: Benign; nasal tumor; neuroendocrine tumor; paraganglioma.
\end{abstract}

Paragangliomas arise from paraganglionic tissues of the extraadrenal autonomic nervous system. Paraganglionic cells are responsible for regulation of blood pressure, blood flow and blood $\mathrm{pH}$ changes in the body. ${ }^{[1]}$ These are usually benign and slow-growing neuroendocrine tumors. Tumors are usually found in the abdomen, thorax, head and neck region. The most common sites of head and neck paragangliomas are the carotid body, jugular bulb, and along the glossopharyngeal and vagus nerves. Carotid body tumors are the most common paragangliomas in the head and neck region. Paragangliomas of the nose and paranasal sinuses are extremely rare. Clinical symptoms and findings of a paraganglioma are related to location of the tumor. ${ }^{[2]}$ Most affected patients experience nasal obstruction, nasal bleeding and facial swelling. ${ }^{[3]}$ In this article we report a female patient with nasal paraganglioma suffering from nasal obstruction and nasal bleeding.
Paragangliyomlar, ekstraadrenal otonomik sinir sisteminin nadir nöroendokrin neoplazmalarıdır. Bunlar genellikle karın, göğüs, baş ve boyun bölgesinde benign ve yavaş büyüyen vasküler tümörlerdir. Baş ve boyun paragangliyomu, primer olarak temporal kemikte ve karotis cisimciğinde bulunur. Burun ve paranazal sinüs paragangliyomları oldukça nadirdir ve çok az olgu sunumu bulunmaktadır. Bu yazıda burun tıkanıklığı ve kanaması eşliğinde nazal paragangliyomu olan 25 yaşında bir kadın olgu literatür verileri eşliğinde sunuldu.

Anahtar Sözcükler: Benign; burun tümörü; nöroendokrin tümör; paragangliyom.

\section{CASE REPORT}

A 25-year-old female patient was admitted to our ENT department with the complaint of nasal obstruction and nasal bleeding of seven months duration. She complained of mild nasal bleeding whenever she attempted to blow her nose. There was no history of nasal surgery, nasal trauma, drug administration, nasal disorders, symptoms related with rhinosinusitis or fever. Anterior rhinoscopy revealed a mass with a smooth surface completely blocking the right nasal passage.

A hypervascular soft tissue mass in the right nasal cavity originated from the right middle meatus (Figure 1). It was situated at the anterior portion of the turbinate. The size at the time of admission was approximately $2 \times 2 \mathrm{~cm}$. She had no cervical lymphadenopathy or cranial nerve deficits. Vision was normal. Computed tomography of the 

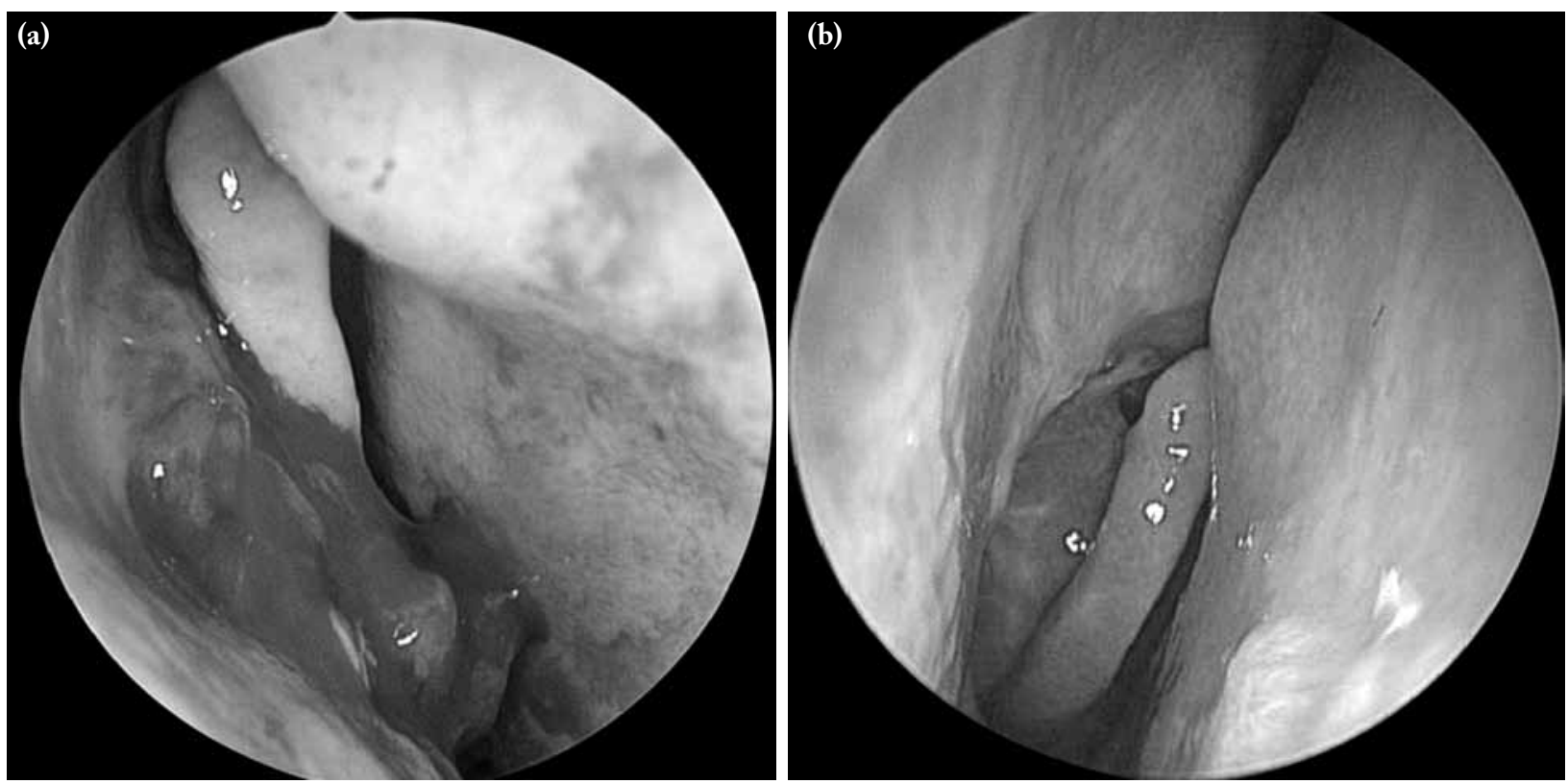

Figure 1. Mass originating from right middle meatus (a) preoperative and (b) postoperative view.

paranasal sinus revealed a soft tissue mass involving the right nasal cavity and originating from the right middle meatus (Figure 2). Coronal magnetic resonance image revealed a mass in the right middle meatus that extended toward the right maxillary sinus and uncinate laterally. Investigations revealed a normal hemogram. Plain X-ray and ultrasound of neck was normal.

Surgical removal of the nasal mass was recommended as a most appropriate treatment option. Transnasal endoscopic surgery was performed under general anesthesia. The mucosa and mass was dissected posteriorly by blunt dissection and stripped from the lateral nasal wall and uncinate. Resection of the mass consisted of a full-thickness excision including a $5 \mathrm{~mm}$ margin of clinically uninvolved tissue. Bipolar coagulation of the mucosa all around the incision was performed. Careful inspection of the operative field was performed to detect any possible remnants. The
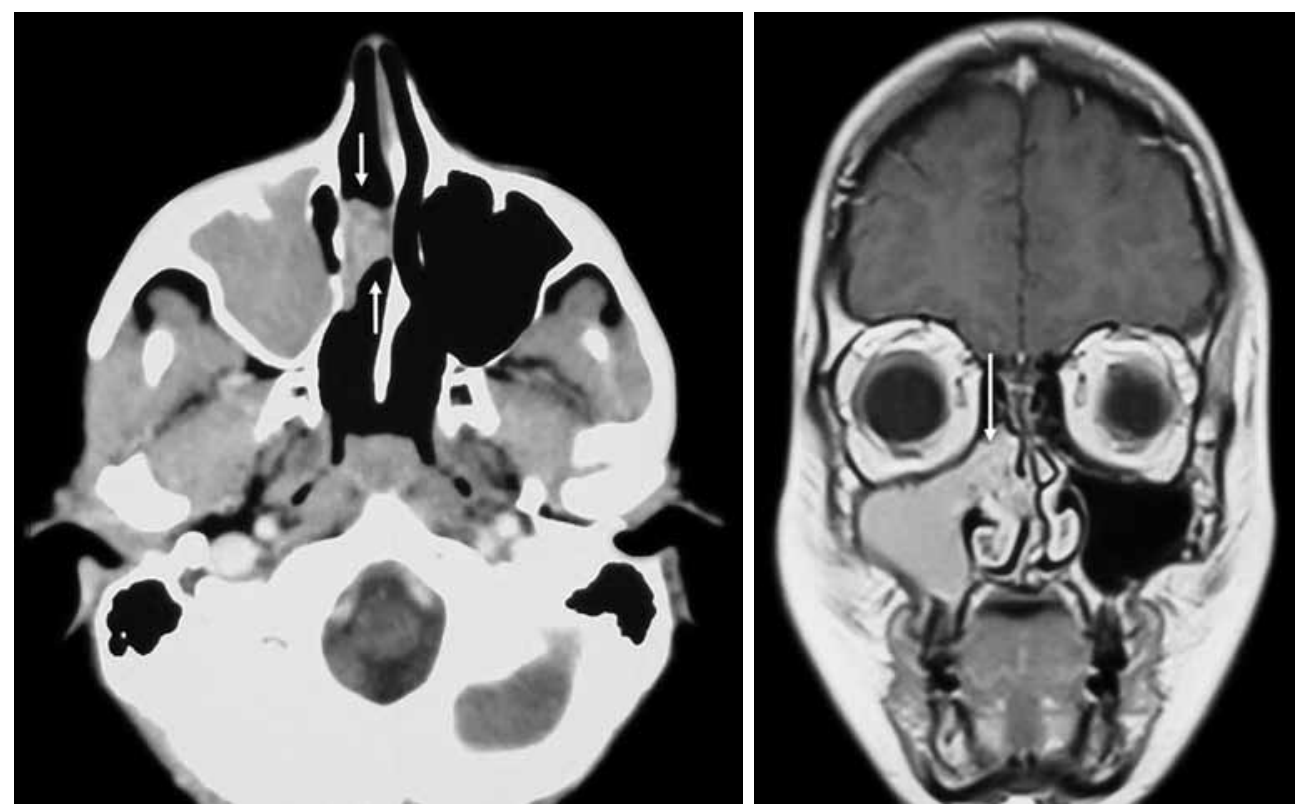

Figure 2. Computed tomography of the paranasal sinus. Soft tissue mass involving the right nasal cavity. Coronal magnetic resonance image reveals a mass in the right middle meatus and extended toward the right maxillary sinus and uncinate laterally. 


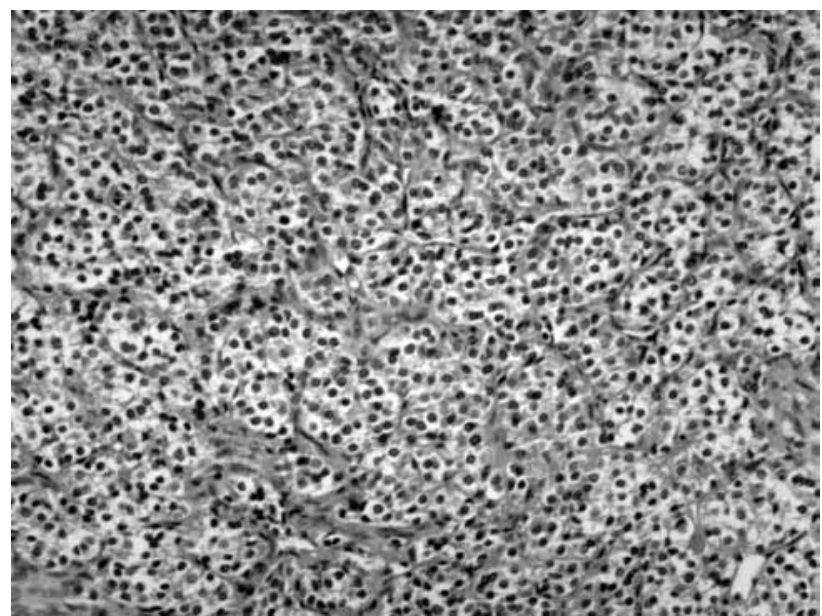

Figure 3. The histological section of the mass. The tumor is composed of cells which have pale eosinophilic cytoplasm and round nuclei. Mitotic figures are usually rare $(\mathrm{H}-\mathrm{E} \times 100)$.

area around the uncinate process and maxillary ostium was hyperemic with small polypoid masses. There was a secondary infection in the maxillary sinus. Mucosal hypertrophy in the maxillary sinus was also noticed. Unilateral functional endoscopic sinus surgery was performed at the same time.

No complications occurred during the postoperative period. Nasal packing was removed after 48 hours. Postoperative recovery was uneventful except for nasal bleeding. Within 20 days, nasal bleeding resolved. Macroscopic examination of the lesion identified a hemorrhagic mass that measured $2 \times 2 \times 0.5 \mathrm{~cm}$ (Figure 3). The mass was diagnosed as a paraganglioma. Endoscopic follow-up for the next two years excluded any residual tumor.

\section{DISCUSSION}

Paragangliomas in the head and neck region more commonly arise in the carotid body, jugular foramen, vagus nerve and middle ear. ${ }^{[4]}$ Less common sites include the larynx, thyroid gland, trachea, face, nose, nasopharynx, mandible, paranasal sinus, soft palate, cheek, orbit, pineal gland, cavernous sinus and cerebellum. ${ }^{[5]}$ Nasal cavity paragangliomas are more prevalent than in the paranasal sinuses. The paranasal sinus tumors are located most often in the ethmoidal sinuses. ${ }^{[4]}$ Paraganglionic tissue has never been found in the adult nasal cavity. Specialized neural crest cells migrate in close association with autonomic ganglion cells. There is a close anatomic association with the pterygoid ganglion and its branches to the location of the nasal paragangliomas. ${ }^{[6]}$ The origin of nasal cavity paragangliomas is not well-known. Several authors have suggested that paraganglionic tissue is present in the pterygopalatine fossa and usually in close association with arteries and cranial nerves. However, most of the nasal cavity paragangliomas were described in the region of the middle turbinate of the ethmoid sinus. ${ }^{[7]}$

The majority of head and neck paragangliomas are benign, slow-growing, encapsulated masses but some are locally invasive. The malignant form of the tumor is uncommon. Histologic criteria are not accepted as a definite sign of malignancy. Malignant paragangliomas are determined to be malignant only if there is the presence of metastasis to cervical lymph nodes or distant sites. $^{[4]}$

The treatment of choice for nasal paraganglioma is surgery. The operative approach is dependent on the extent of tumor invasion. Nasal paragangliomas are generally localized and complete excision is curative. Paragangliomas that are typically more advanced at the time of diagnosis require complete evaluation by computed tomography and arteriography to determine the tumor extent. Irradiation and tumor embolization are the other therapeutic options for unresectable or partially-excised tumors. ${ }^{[8]}$

\section{Conclusion}

Paragangliomas arising in the head and neck region are exceedingly rare. The clinical presentation is related to location and nasal paragangliomas present with nasal obstruction and nasal bleeding. The clinic and radiological findings are not characteristic, and should be differentiated from other nasal pathologies. Early diagnosis and complete surgical removal offers the best chance of survival.

\section{Declaration of conflicting interests}

The authors declared no conflicts of interest with respect to the authorship and/or publication of this article.

\section{Funding}

The authors received no financial support for the research and/or authorship of this article.

\section{REFERENCES}

1. Bednar MM, Trainer TD, Aitken PA, Grenko R, Dorwart $\mathrm{R}$, Duckworth J, et al. Orbital paraganglioma: case report and review of the literature. Br J Ophthalmol 1992;76:183-5.

2. Churojana A, Boonthathip M, Suwanagool P. Paragangliomas of the head and neck: a retrospective review at Siriraj Hospital. Siriraj Med J 2007; 59: 52-9

3. Mevio E, Bignami M, Luinetti O, Villani L. Nasal paraganglioma. A case report. Acta Otorhinolaryngol Belg 2001;55:247-9. 
4. Pellitteri PK, Rinaldo A, Myssiorek D, Gary Jackson C, Bradley PJ, Devaney KO, et al. Paragangliomas of the head and neck. Oral Oncol 2004;40:563-75.

5. Moyer JS, Bradford CR. Sympathetic paraganglioma as an unusual cause of Horner's syndrome. Head Neck 2001;23:338-42.

6. Sharma HS, Madhavan M, Othman NH, Muhamad M, Abdullah JM. Malignant paraganglioma of frontoethmoidal region. Auris Nasus Larynx 1999;26:487-93.

7. Meher R, Garg A, Piyush A, Raj S. Singh: malignant paraganglioma of the nose. The Internet Journal of Otorhinolaryngology 2006;5. Available from: http://ispub. com/IJORL/5/2/11954

8. Kuhn JA, Aronoff BL. Nasal and nasopharyngeal paraganglioma. J Surg Oncol 1989;40:38-45. 